\title{
E - Banking in Sudanese Banking Sector: Between New Opportunities and Challenges
}

\author{
Dina Ahmed Mohamed Ghandour
}

\begin{abstract}
Development of information technology in the last few years, have brought about a lot of changes in almost all facets of life. In the banking industry, it has been in the form of banking services offered through an electronic channel. Electronic banking is the wave of the future, it has a lot of benefits which add value to customers' satisfaction in terms of better quality of service offerings and at the same time banks can gain more competitive advantage over other competitors. Despite this there are a lot of challenges that may hinder the success of e-banking services and thus constitute major concern to both financial institutions and customers.

The purpose of this paper is to investigate and focus on the different opportunities and services of e-banking in Sudanese banking sector, and the challenges associated with it. Regardless, the different e-banking services found in Sudan but still there are a lot of challenges associated with its successful implementation. This paper followed the analytical/qualitative method to investigate such a problem. Both primary and secondary data were collected, and excel was used to analyze collected data.
\end{abstract}

Keywords - E-banking, Sudanese banking sector, Opportunities and challenges, e-banking services.

\section{Introduction:}

Rapidly growing of Information technology has changed the way financial transactions are done in banking industry globally. This form of technological advancement has enhanced the delivery of banking services, and was reflected in the introduction of E-banking (electronic banking).

E-banking means an electronic handling of all types of banking transactions, primarily over the internet. Through ebanking any user with a personal computer and a browser can get connected to his bank -s website to perform any of the virtual banking functions. In internet banking system the bank has a centralized database that is web-enabled. All the services that the bank has permitted on the internet are displayed in menu. Any service can be selected and further interaction is dictated by the nature of service.

E- Banking uses today's computer technology to give user the ability to manage their finances more quickly and efficiently, from anywhere around the world, and with just a click of the mouse. Banks perceive online banking as a powerful 'value-added' tool to attract and retain new customers, while helping to eliminate costly paper handling

University of Medical Sciences and Technology

Faculty of Business Administration

Department Of Accounting and Finance

Khartoum, Sudan and teller interactions. E- Banking has managed to provide customers the convenience, efficiency, effectiveness, and most importantly, the speed needed in today's dynamic world. As more banks around the world are offering online banking to its customers, it is becoming a rather popular trend. However, countries like Sudan started to offer this service but still it's far away from implementing this new innovation in an effective manner.

\section{E-banking services:}

Electronic banking can be divided on the basis of the instruments used: the below figure shows these instruments and their sub divisions;
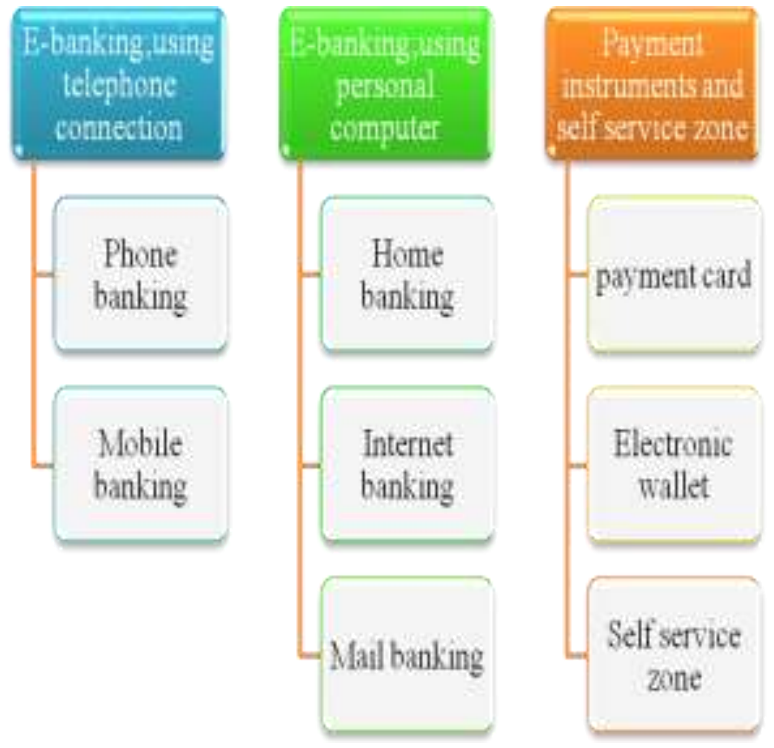

Figure 1; E-banking services

\section{Electronic Banking Using a Telephone Connection:}

Electronic banking using a telephone connection can be divided in to two:

- Phone banking (ATS) and

- Mobile banking (SMS banking, GSM SIM Toolkit and WAP).

Phone banking; Is the provision of banking services using a classic telephone line. A bank client can obtain the necessary information on dialing a telephone number specified in advance. Before the requested banking service information is provided, the client's identity is determined using contractually agreed terms.

The client advisor or so-called telephone banker is a bank employee capable of providing any information about 
products and services and, following verification that he is speaking with an authorized person, can also perform any passive or active operation. He can provide advice to the client and offer further banking products.

\section{a. Automated Telephone System;}

An automated telephone system works on the basis of a menu through which clients can move around using buttons on the telephone. The service menu tree is usually designed to be simple so that a choice does not take too long. More extensive information is sent to the client by fax either to a telephone number agreed in advance or to a number requested by the client.

Mobile banking: mobile banking can take the following forms;

\section{a. SMS Banking:}

SMS banking uses short text messages sent through the client's mobile phone. SMS text messages can be used for both passive and active operations similarly as with classic telephone banking. A client can automatically receive information about his account balance, an SMS is sent to the client immediately after a certain operation is performed, or on request: a client sends the bank a correctly formatted message which processes it and answers the client's request by SMS.

\section{b. GSM SIM Toolkit:}

The GSM SIM Toolkit service can only be used from a mobile phone supporting this technology. GSM SIM Toolkit is a software interface that enables arbitrary changes to the mobile phone menu. Operators supporting this technology can use it to personalize mobile phone menus. This means that only functions activated and paid for will appear on the user menu. This technology dates back to 1998. Among the first companies to use it in banking applications based on the GSM SIM Toolkit standard were RadioMobil and Expandia Bank in the Czech Republic.

\section{c. WAP (Wireless Application Protocol):}

WAP is often compared to web pages, although this is a simplification. Unlike pages appearing on a computer monitor, WAP presents its output on a small mobile phone display, therefore concentrating on text information. It is a form of gateway to various services prepared by a mobile network operator or another firm. One condition for using the service is that the client must have a mobile phone supporting WAP technology.

\section{Electronic Banking using Personal Computers:}

Electronic banking through personal computers can be divided into:

\footnotetext{
- Home banking, Internet banking and Mail banking a. Home banking:

Home banking is a service that enables a bank client to handle his accounts from a computer from a place selected in advance, at home or in the office. A home banking system usually consists of two parts: a bank computer program and a program in the client's computer. The bank program works as a communication server. It receives calls from clients, verifies their identity, receives data from them, authenticates digital signatures, generates digital receipts and sends data to clients.
}

b. Internet Banking:
Internet banking can be used from the home or the office, as well as an internet café, although the latter is not recommended for security reasons.

\section{c. Mail banking:}

Mail banking is another electronic banking service that makes it possible to communicate with the bank by electronic mail i.e. e-mail. The most frequently used service is sending account statements at agreed periodicity to the client's mailbox. E-mail is not used for more complex operations.

\section{Payment Instruments and Self-Service Zones}

There are other forms of electronic banking, including; a payment card, an electronic wallet and a self-service zone.

A payment card is currently one of the most widely used payment instruments designated for authorized holders through which they can perform non-cash payments or cash withdrawals from an extensive network of automated teller machines.

An electronic wallet represents a chip card similar to a payment card that contains a record of a financial sum that is available to its owner.

A self-service zone is a fully automated alternative work place of a bank with terminals and devices that clients can use to get various bank services. It enables active and passive operations offered by the bank to be made without the presence of a bank employ.

Historical background of E-banking in Sudan:

Electronic banking in Sudan was first introduced in 1999 when the Central Bank of Sudan (CBOS) took the initiative to introduce modern information technologies in Sudanese banking industry as a part of its banking system development plan for 1999-2000. In 1999 the CBOS established the Electronic Banking Services Company (EBS) to be responsible for building and developing ebanking industry in Sudan. EBS is a private company owned by CBOS (49\%), Sudatel Telecom Group (30\%) and the Sudanese banks (21\%). It started its operations in 2000 and is committed toward introducing banking technologies and solutions, and most importantly payment systems.

EBS is in charge of the following six major systems hosted at or delegated by CBOS:

SWIFT: a shared worldwide data processing and communications link and a common language for international financial transactions came to Sudan in 2000, National Switch: was established in 2006 to provide Automatic Teller Machine services, Electronic Point of Sale service, Electronic Funds Transfer and allows Sudanese banks communication,

Electronic Cheque Clearance (ECC): ECC was established in Sudan in 2007, it's an electronic imagebased check clearing solution, designed to provide end-toend nationwide clearing of cheques within the same day,

Real Time Gross Settlement: it's a funds transfer mechanism, in which money is transferred from one bank to another on a "real time" and on "gross" basis. This is the fastest possible money transfer system through the banking channel,

Electronic Link system, the core banking system of CBOS, and

- Electronic Reports system for CBOS and commercial banks. 


\section{Problem Statement:}

During the last years almost all banks in Sudan embraced the new technology and gradually started to offer electronic banking services to their customers. The banking sector drive towards technology might have been partially an effort to put up with global standards. Other possible reasons may include cost reduction, the entrance of foreign banks into the Sudanese market and the increased competition among banks.

However, despite the benefits and new services of electronic banking, still it is argued that the use of e-banking in Sudan is weak.

\section{Main reasons for the problem:}

Lack of co-ordination between the private and public sectors to create the right environment for banking, lack of awareness of e-banking and distrust of online payments and security, lack of legal protection against online intrusions, Inadequate infrastructure, computer internet literacy and connectivity, lack of computer skills, lack of privacy and confidentiality of bank's accounts and High e-banking.

\section{Significance of the study:}

The significance of this study is conducted in order to:

- Understand the issue of e-banking and its evolution in Sudan.

- Spotlight on e-banking services offered in Sudanese banking sector.

- Highlight the challenges of e-banking in Sudan.

- Identify the factors that influence the adoption of ebanking in Sudan.

\section{Objectives of the Study:}

The general objective of this study is to: Explore the development of e-banking in Sudan, highlight the different electronic banking services and opportunities available in Sudanese banking sector, and to study carefully the challenges of electronic banking in Sudan.

\section{Hypothesis:}

E-banking will improve the efficiency and effectiveness in the banking sector, if it is given a considerable attention and implemented properly. All e-banking challenges will be reduced, if it has been accepted by consumers and a reasonable awareness is made to them regarding its usage and the volume of banking services offered through an electronic channel.

\section{Target Population:}

The targeted population of the study is the financial institutions that offer e-banking services in Sudan and ebanking clients as well.

\section{Materials and Methods:}

To meet the research objectives, the research is going to be based on analytical and qualitative methods. Excel was used to analyze the collected data.

\section{Data Collection:}

Two types of data sources can be integrated; secondary data and primary data. Secondary data is used to gain initial insight into the research problem; it is required in the preliminary stages of research to determine what is known already and what new data is required. Primary data is data that did not exist before. It is designed to answer specific questions of interest of the researcher.

\section{Secondary data:}

Secondary data was obtained from the internet, text books, newspapers and journals.

\section{Primary Data:}

Primary data was collected by conducting an interview with banks managers and employees who are responsible about the electronic channel.

\section{Discussion:}

This paper will spotlight on electronic banking services in Sudanese banking sector in terms of;

The evolution of e-banking in Sudan, the new opportunities and different services that are offered through an electronic channel.

The challenges that are associated with the implementation of e-banking in Sudanese banking sector.

Evolution of E-banking in Sudan: E-banking was first introduced by Omdurman National bank in 2003, by installing the first ATM, after that the numbers of ATMs has increased steadily. The below bar chart shows an increase in the number of ATMs in Sudan between 2006 and the present.

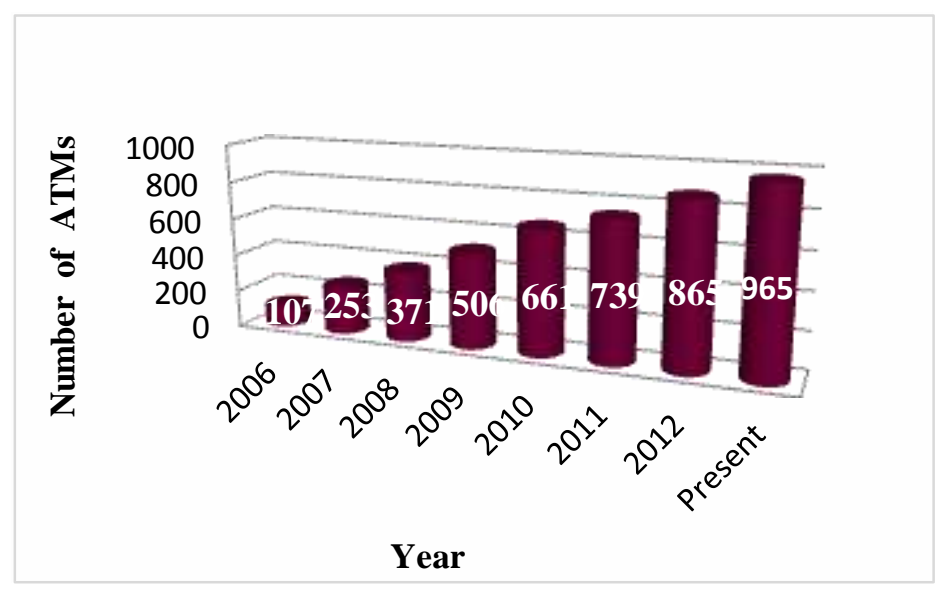

Figure 2; Number of ATMs

\section{Description of ATMs;}

ATMs consist of the following components:

Safe; this contains money that would be drawn by customers and for money which could be deposited by them. The safe could not be opened except by authorized personnel only.

Small colored screen and key board; through which customers confers with the machine and send their requests. It shows in steps what to do; the screen is used for promotion when there are no customers.

Magnetic and smart cards reader; to read the information from the cards to exercise the requested operations.

In Sudan, the number of ATM cards issued by the banking sector has increased over time, as result of the increase in the number of ATMs machines and the usage by clients. The below chart clarifies this, by presenting the number of cards that were issued between 2006 and the present. 


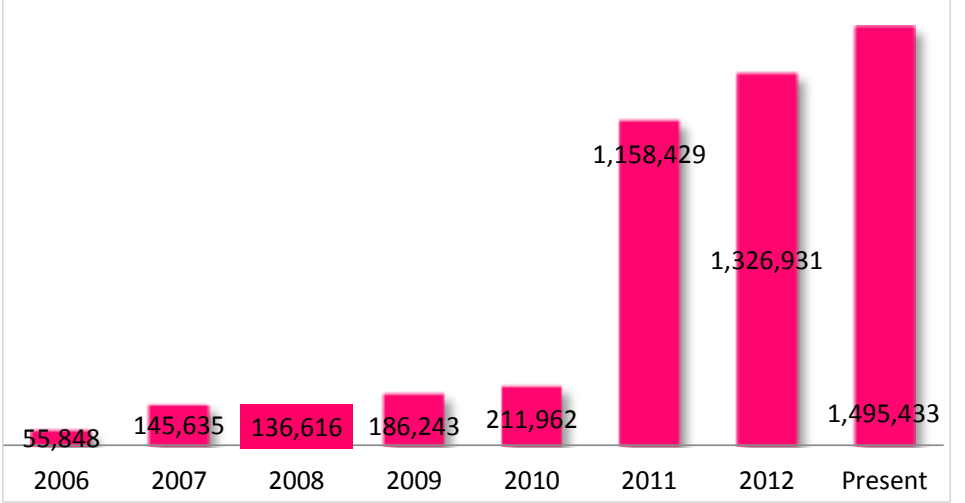

Figure 3; Number of Cards

Small printer; for printing vouchers of the achieved operations and the information, requested by customers.

Secured boxes, one for the money, which the machine fails to deal with, the other is for the cards that have been taken by the machine to forbid unauthorized and misuse.

Lately cameras are added to some machines, to prove the usage of the machine by certain persons and they are generally for security purposes.

The machines are connected through a net with a center for all the banks (Switch), or for a certain bank, to organize and permit or forbid operations exercised through machines.

Available ATM services in Sudan ; ATM services include cash withdrawal, balance inquiry, mini account statement, pin change, transfer money between accounts, bills payment, buying prepaid mobile and electricity recharge cards, and cash deposit which is offered presently by Fiasal Islamic bank only.

Throughout time Sudanese banks started to expand their electronic banking channel. At present Sudanese banks are offering e-banking services through ATMs, internet, and EPOS (electronic point of sale service) .Moreover, the latest service, which is now available in Sudanese banking institutions, is the mobile banking (M-banking) service. It is one of the newest approaches to the establishment of financial services through information computer technology (ICT), made possible by the widespread adoption of mobile phones even in low income countries. As per the Central Bank of Sudan (CBOS) information; there are only 2 banks among 37 banks operating in Sudan are providing the mobile banking service. Thus; it is expected that in the upcoming period of time this service will spread gradually in the banking sector in Sudan.

Despite the different electronic banking channels, but still there are a lot of challenges associated with its adoption and successful implementation.

\section{Challenges/Problems of E-banking in Sudan:}

There are a lot of challenges and factors that influence the successful implementation of e-banking in Sudan. Such challenges can be divided in to two; the challenges that are facing the banking sector and those that are coming from the clients i.e. customers' acceptance and intention to use bank technologies.

\section{Banking perspective;}

The banking sector in Sudan is faced by following challenges, which may hinder the successful implementation of e-banking;

Costs: Costs' arising from the acquisition and maintenance of new information technology is very high. It is observed that the cost of establishing networks and tariffs charged are so high that even if computers, are available it is only the privileged few who can have access to the service.

Standardization: In banking institutions, there is also the problem of the standardization of hardware facilities. The information superhighway has engineered the importation of various brands of information technology by Financial Institution. Technologists assert that imported technologies are designed to operate in an air-conditioned, dust free environment with a good maintenance support. In Sudan, such conditions may not always be available.

Illiteracy: Illiteracy in banking institutions is one of the serious constraints to the effective use of information technology. The quality of training in information communication technology is also unsatisfactory. Introduction to physical equipment will not solve the problem of information availability and flow, unless it is coupled with human capacity and skills.

Infrastructure: Lack of infrastructure remains the main setback to the development of information communication technologies in banking institution. Telephone line failures and electronic blackouts are frequently experienced.

Security: The reliance on new technology to provide services makes security and system availability the central operational risk of electronic banking. Security threats can come from inside or outside the system, so banking regulators and supervisors must ensure that banks have appropriate practices in place to guarantee the confidentiality of data, as well as the integrity of the system and the data. Banks' security practices should be regularly tested and reviewed by outside experts to analyze network vulnerabilities and recovery preparedness.

Customers/Clients perspective: Bank customers have been, for a long time, familiar to classical mode of banking, where customers interact with banks personally. The introduction of electronic banking has changed the banking services, as customers now are expected to deal with the electronic channel. This additional burden on customers, together with the uncertainty surrounding the process may not encourage customers to embrace the new banking technology. For this reason, the acceptance of technology must not be looked upon as an easy decision as may initially seems. However, the following problems may face customers when encountering with such technological changes, such as;

Anxiety and stress; caused by the use of information technology, or the confusion about how arising technology problems may be solved

Cost: Technology learning and acquisition is costly, especially in a developing country such as Sudan, where cost is likely to be a determining factor.

Security; a lot of clients have the view that if they used the electronic channel there personal information can be stolen. 
Applying the Technology Acceptance Model (TAM) in Sudanese Banking Sector:

In 1989 Davis, has developed a model which is Technology Acceptance Model (TAM); it's an information systems theory that models how users come to accept and use a technology. The model suggests that when users are presented with a new technology, a number of factors may influence their decision about how and when they will use it. It successfully explored the behavioral intentions as "The degree to which a person has formulated aware plans to perform or not perform some specified future behavior" .The model includes four variables which are; Perceived Usefulness, Perceived Ease of Use, Perceived Risk and Perceived trust.

The below figure clarifies the Technology Acceptance Model;

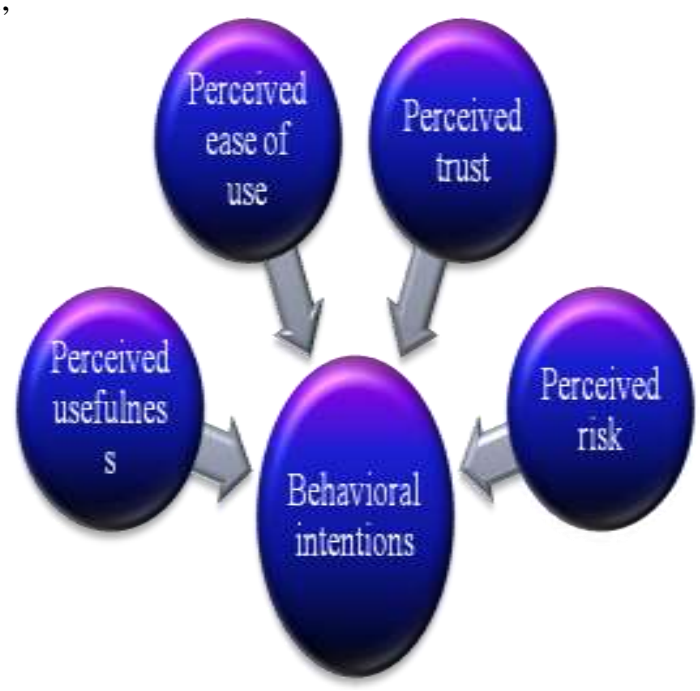

Figure 4; Technology Acceptance Model;

\section{Perceived Usefulness (PU):}

Perceived usefulness (PU) is one of the main constructs of the technology acceptance model TAM in which it is defined as "the degree to which a person believes that using a particular system would enhance his or her job performance". In the TAM, PU is a significant factor having a strong influence in determining user acceptance of IS.

Applying this definition to e-banking adoption in Sudan; perceived usefulness is the perception of users that ebanking will enhance their means of getting the bank services. However, now a days a lot of people started to get the perception of dealing with the electronic channel and that following such a channel will facilitate a lot of things to them .This can be seen in the usage of ATMs, a lot clients believed that it's more easier to withdraw money from ATMs instead of going to banks and waiting for a long period of time .Despite this, still such a perception is very few when dealing with the other e-banking services.

\section{Perceive Ease of Use (PEOS):}

Perceived ease of use (PEOU) is defined as "The degree of ease associated with the use of the system". It provides the leverage to create favorable perceptions, encouraging users to accept and use new systems, .PEOU in case of e-banking is considered as the degree to which e-banking is perceived to be easy to access and use. In Sudan still a lot of people find difficulty to access and use the electronic channel, this may be due to lack of computer skills and lack of awareness of e-banking.

\section{Perceived Trust (PT):}

Trust is being normally defined as belief that someone or something is reliable, good, honest, effective, etc. In Sudan very few clients trust to engage in an online transaction as they distrust online payments and security.

\section{Perceived Risk (PR):}

Generally; risk can be defined as the intentional interaction with uncertainty. Risk perception is the subjective judgment people make about the severity of a risk. In Sudan, Conducting electronic transaction is a risk that faces consumers, as it does not have any kind of physical contact, which subsequently; affects the adoption to internet technology. As a result, a lot of clients who already conduct the financial transactions manually find it difficult to shift and follow the electronic channel, since they perceive it as more risky and less private. For example; they think there is no privacy and confidentiality in personal and financial information, frequent power cut offs, frequent breakdown of ATMs, frequent errors of e-banking transactions...etc.

\section{Conclusion/Recommendations:}

Offering banking services through an electronic channel has a lot of benefits to the banking sector and clients as well. However, here in Sudan despite the adoption of this service but still there are a lot of challenges and problems faced by banks and their clients. This paper has introduced the different electronic banking services in Sudanese banking sector and the challenges associated with it. At the end, in order to strength the electronic banking channel and to encourage clients to conduct their transactions electronically, the following recommendations can be portrayed;

- There should be proper maintenance of the system used by the banks in order to prevent cases of complete breakdown of the system. This can result in loss of information that are of vital importance to the customers and banks.

- E-banking should be easily accessible by the users; in terms of convenience, availability, understanding and suitability.

- Improved Internet connectivity is very essential for the success of e-banking. For this reasons, government has to play a major role in promoting the basic infrastructure required to increase the diffusion of e-banking. This includes provision of stable supply of electricity and latest information and communication technologies.

- E-security serves as a serious concern not only to the banking industry but also the clients. There are various measures that can be put in place to ensure more security using e-banking services such as installation of encrypted software, verification system for customer's identification cards, frequent change of password, examining test questions and using mixed password such as the use of alphanumeric; 
- Last but not least, Sudanese banks could enhance the promotion of banking services by implementing awareness programs to their current and potential clients on the benefits of using e-banking.

\section{Acknowledgment:}

I would like to take this opportunity to thank all the Business Administration Teachers whom, through their, encouragement I have gained and grown.

My deepest appreciation is expressed to my beloved mother for her blessing, endless support, and love. My sincere gratitude to my brothers for their consistent encouragement and support.

\section{References:}

1) Alam, Nafis; Magboul, Ibrahim Hussien Musa; Raman, Murali, 2010, Challenges Faced by Sudanese Banks in Implementing Online Banking: Bankers' Perception.

2) Almobark, Miada Mohamed ,2013, An Experimental Study of E-Banking service channel with reference to mobile Banking in Sudan, repository.sustech.edu/jspui/handle/123456789/1935

3) Basel Committee on Banking Supervision, 2003, Risk Management Principles for Electronic Banking.

4) Definition of E-banking - Notes, http://sjecnotes.weebly.com/uploads/5/2/5/1/5251788/2 6494919-definition-of-e-banking.pdf

5) Dr. Ilham Hassan F. Mansour, Dr. Abuzar M. A. Eljelly, Dr. Abdelgadir M. A. Abdalla,2014, ww.researchgate.net/publication/268747607_Consumer $\mathrm{S}$

6) Dr. Saritabahl,2012,E-banking: Challenges \& Policy Implications, www.researchmanuscripts.com/isociety2012/65.pdf

7) Electronic Banking Services Co. Ltd - EBS, www.ebssd.com/en/careers-at-ebs.php

8) Electronic Banking - Terms and Conditions, 2015, www.commbank.com.au/personal/apply-online/...

9) Ing. Adriana Chovano,2006, Forms of Electronic Banking, www.nbs.sk/_img/Documents/BIATEC/BIA06_06/22_ 25.pdf

10) Jayshree Caavan, 2013, Internet Banking- Benefits and Challenges In an Emerging Economy, www.impactjournals.us/download.php?fname $=--$ 1371887005-3

11) Jun $\mathrm{Wu}, 2005$,Factors that influence the adoption of internet banking by South Africans in the Ethekweni metropolitan region, ir.dut.ac.za/handle/10321/114

12) Mohamed A. Ismail, Mohammed A. Y. Osman, 2012, Factors Influencing the Adoption of E-banking in Sudan: Perceptions of Retail Banking Clients, citeseerx.ist.psu.edu/viewdoc/summary?doi=10.1.1.299. 3706

13) Mustafa Hassan Mohammad Adam, 2013, Electronic Banking Problems and Opportunities: The Sudanese Context", www.iiste.org/Journals/index.php/EJBM/article/downlo $\mathrm{ad} /$.

14) Nancy George Karma, Dr. Siddig Ballal Ibrahim, Dr. Abdel Hafiez Ali, 2014, Key Factors Affecting Mobile Banking Adoption Among Banks Customers In Sudan.

15) Nikolaï Partnov,2013 ,Thibault Estier, ,E-Commerce Applications Evolution Issues: the case of E-Banking, ceur-ws.org/Vol-456/paper5.pdf
16) R. A. Gbadeyan, O.O. Akinyosoye,2011, Customers' Preference for E-banking Services: A Case Study of Selected Banks In Sierra Leone, www.ajbmr.com/articlepdf/ajbmrv01n0412.pdf

17) Shilpan Vyas, 2012, Impact of E-Banking on Traditional Banking Services, http://www.ijcscn.com/Documents/Volumes/vol2issue3/ ijescn2012020303.pdf.

18) Winfred Ofoe Larkotey, Ed. Danso Ansong, Dominic Damoah, Ebenezer Laryea,2012, Attitudes of Customers toward the use of ATMs in Sub Saharan Africa: A Case Study of Ghana, www.irjcsea.org/vollissue3/paper25.pdf

About Author (s):

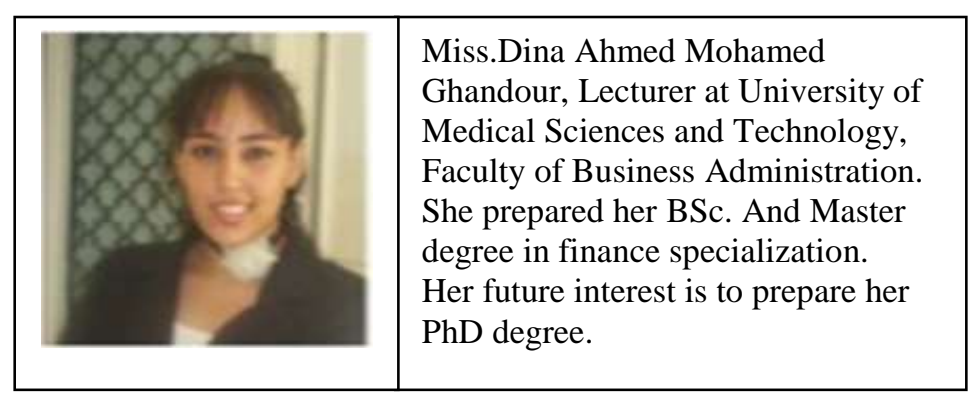

